DOI: https://doi.org/10.18371/fp.2(34).2019.178403

УДК $347.9 ; 346.1$

\title{
ТЕОРЕТИЧНІ АСПЕКТИ ПРОЦЕДУРИ ВИКОНАННЯ СУДОВИХ РІШЕНЬ В УКРАÏHI
}

\section{БРАЙЧЕНКО Сергій Миколайович}

кандидат юридичних наук, дочент кафедри права

і соиіально-гуманітарних дисииплін

Черкаського інституту ДВНЗ «Університет банківської справи»

ORCID ID: http://orcid.org/0000-0002-4429-0770

e-mail: bsnchk@i.ua

\section{ФОМЕНКО Валентина Миколаївна}

викладач кафедри права і соціально-гуманітарних дисциплін

Черкаського інституту ДВНЗ «Університет банківської справи»

ORCID ID: http://orcid.org/0000-0002-2778-8390

e-mail: tinabogunova@gmail.com

Анотація. Стаття присвячена актуальним проблемам виконання судових рішень в Україні, шзо прийнято розглядати, як завершальну стадію иивільного та господарського прочесу. Проте існують альтернативні наукові бачення, які також висвітлено. Акцентовано увагу на теоретичному обтрунтуванню одночасного функиіонування в Україні інститутів приватного та державного виконання судових рішень. Також розглянуто сучасні доктринальні підходи щзодо визначення поняття «провадження» та відзначається сутність відмінностей між обтрунтуваннями вченими-правниками своїх наукових позииій.

Ключові слова: ичивільний процес, господарський прочес, державний виконавець, приватний виконавець, стадія провадження, судове рімення.

Постановка проблеми. Неналежне виконання судових рішень має негативний вплив як на авторитет судової влади, так і України, як держави, яка
Аннотация. Статья посвящена актуальным проблемам исполнения судебных решений в Украине, что принято рассматривать как завершаюшую стадию гражданского и хозяйственного проиесса. Однако существуют альтернативные научные видения, которые также здесь отражены. Акиентировано внимание на теоретическом обосновании одновременного функиионирования в Украине институтов частного и государственного исполнения судебных решений. Также рассмотрены современные доктринальные подходы к определению юридического термина «производство» и отмечается сущность различий между обоснованиями учеными-юристами свочх научных позищий.

Ключевые слова: гражданский прочесс, арбитражный процесс, государственный исполнитель, частный исполнитель, стадия производства, судебное решение.

зобов'язана забезпечити надійне функціонування державно-правового механізму, одне із призначень якого досягнення кінцевої мети правосуддя, 
яка полягає в захисті прав та інтересів осіб та реальному поновленню їх порушених прав.

На сьогоднішній день, виконання судового рішення - це невід'ємна складова права особи на судовий захист та охоплює нормативно визначений комплекс дій, які спрямовано на захист та відновлення порушених прав, свобод, законних інтересів фізичних та юридичних осіб, суспільства та держави.

Розгляд справи в суді прийнято поділяти на процесуальні стадії, однією iз яких виступає і стадія виконання рішень. Однак одностайності між правниками у виробленні підходів до класифікації стадій, на сучасному етапі не має. Між науковцями відбуваються дискусії щодо наукового тлумачення поняття виконання судового рішення. Вчені, які досліджують дану тематику, мають дещо протилежні бачення. Чи так важливо досліджувати, чим саме $\epsilon$ виконання рішення суду: окремим провадженням щодо реалізації прав сторін чи однією із стадій адміністративного цивільного або господарського процесу.

Сутність дискусій між науковцями щодо стадій процесу полягає в тому, що має місце ототожнення стадій 3 процесуальними провадженнями. Слід відрізняти процес захисту права особи в ході виконання рішень, перш за все за суб'єктним складом за змістом правових відносин від процесу захисту права особи в суді. В будь-якому разі, усі ці стадії лишаються складовими єдиного процесу захисту прав особи, який не можна вважати закінченим без відповідного виконання рішення суду. Слід також звернути увагу на те, що серед правників досягнуто одностайності в ототожненні понять «провадження» і «стадія», що неодмінно тягне за собою необхідність розгляду процесу виконання рішення як провадження [1, с.922].

Слушною, хоча не менш дискусивною $є$ позиція вчених, які досліджують проблеми господарського процесуального права. На думку Балюка I.А., виконання судових рішень - це стадія господарського процесу, у якому спеціальні державні органи здійснюють примусову реалізацію прав суб'єктів господарювання, застосовуючи процесуальні форми. Дана стадія виконання рішень, на думку вченого, $\epsilon$ стадією господарського процесу [2, с.189]. На підтвердження цієї ідеї, необхідно визнати, що виконавче провадження здійснюється виконавцями у тісній взаємодії та під контролем суду, при цьому господарський суд бере безпосередню участь у виконанні рішення.

Слід внести уточнення у приведене формулювання, оскільки воно датується 2008 роком, хоча на сьогодні, у зв'язку зі змінами до законодавства, примусове виконання судових рішень i рішень інших органів (посадових осіб) (далі - рішення) покладається на органи державної виконавчої служби та у визначених Законом України «Про виконавче провадження» випадках - на приватних виконавців [3].

Оскільки, господарське судочинство розвивається в певній послідовності, за стадіями, то і стадія господарського процесу розглядається як сукупність процесуальних дій по окремо взятій справі, які спрямовані на певну процесуальну мету, що характеризу- 
ється специфічним змістом, широким колом суб'єктів процесуальної діяльності та особливим процесуальним й документальним забезпеченням [4, c.14-17]. Кожна стадія господарського процесу має специфічний характер, що зумовлено об'єктом цих відносин, суб'єктним складом учасників на певній стадії, метою та змістом їі процесуальних дій.

Автори погоджуються 3 думкою Єфімова О.М., що саме зміст і мета, проміжна або прилегла, $є$ головним критерієм розподілу господарського процесу на стадії. Стадія цивільного процесу - це сукупність процесуальних дій, що об'єднанні відповідною процесуальною метою, оскільки усі стадії цивільного процесу спрямовані на досягнення тотальної мети - здійснення правосуддя.

Ряд вітчизняних вчених, також наполягають, що цивільне судочинство складається 3 окремих стадій або частин, що характеризуються сукупністю процесуальних правових відносин, дій, та об'єднаних найближчою метою [5, c.56-58].

Цілком зрозуміло, як цивільний i господарський процес, так і адміністративне судочинство, потрібно поділяти на стадії, кожна 3 яких має відмінність від інших за своїм змістом та за метою процесуальних дій, що вчиняються судом на певному процесуальному етапі. Усі стадії законодавчо впорядковано та спрямовано на досягнення генеральної мети судочинства, після того, як досягнуто найближчу процесуальну мету, що характерна для відповідної стадії. Однак, предметом дискусії залишається - чи відносити виконання рішень до процесуальних стадій певного виду судочинства? Окрема група вчених висловлює переконання, що стадія виконання судових рішень у повній мірі відповідає характеристикам стадії процесу, а виконавче провадження визначається, як окрема стадія цивільного процесу, оскільки застосування норм матеріального права до спірних правовідносин з метою усунення порушення прав або інтересів особи не $\epsilon$ захистом ii прав та інтересів [6, с.24].

В ході вивчення даної наукової проблематики, автор дослідив думку, яка базується на іншій науковій позиції. Інша група вчених, погоджуючись 3 тим, що стадією цивільного процесу $є$ сукупність процесуальних дій, які поєднані найближчою процесуальною метою, проте, виконання судових рішень не розглядаються, як стадія процесу, зокрема, цивільного [7]. За такими твердженнями, виконавче провадження - це самостійне процесуальне провадження, а не частина певного процесу.

В загальноприйнятому розумінні, одним із учасників процесуальних правовідносин виступає суд, тому не всі правовідносини, зокрема правовідносини між виконавця та боржником або стягувачем, без участі суду, можна назвати процесуальними. Виконання судових рішень, не зважаючи на єдність із процесом захисту прав особи в суді, в певній мірі $є$ самостійним процесом, у якому правовий статус учасників $є$ відмінним від їх правового статусу у цивільному процесі, при цьому загальна мета щодо захист права особи лишається незмінною.

Розглядаючи наведені визначення, автор дійшов розуміння, що вітчизняні 
правники поділяють на стадії провадження процес розгляду справи в суді, а не безпосередньо процес виконання судового рішення. Також необхідно визнати, що встановлено певний зв'язок у структурному плані між стадіями та провадженнями у процесі. Здійснюючи порівняння стадій та проваджень можна дійти висновку, що стадії виражають собою динамічну характеристику процесу, тоді, як провадження - предметну. Саме тому, науково коректно, для позначення процедури виконання рішення юрисдикційних органів, застосовувати термін «стадія», оскільки термін «провадження» застосовується в результаті термінологічної інерції законодавця [7; с.20-23]. На думку автора, є сенс підтримати дану позицію в частині того, що процес виконання рішень не потрібно розглядати в якості провадження. Доцільно розглядати виконання рішень, як фінальну стадію захисту прав особи в судовому процесі. Цікавою також видається спроба науковців-процесуалістів структурно поєднати провадження і стадії процесу. Тобто, виділяти не стадії процесу в цілому, а стадії окремо взятих видів проваджень за інстаційною ознакою. Характерно, що для кожного виду провадження можуть бути свої специфічні стадії, визначено їх чисельність, строки та послідовність. Стадії судочинства слідують одна за однією чим декларують єдність та нерозривність процесу захисту прав особи [8]. Також, кожна стадія ставить перед собою процесуальну мету. Розподіляючи процес захисту прав особи на стадії, слід визначати процесуальну мету кожної з них, при тому, що конкретна мета стадії має узгоджуватися із головною метою судочинства - захистом прав особи, тож кожна стадія судочинства є проміжною ланкою процесу.

Підсумовуючи першу частину свого дослідження сучасних проблем виконання судових рішень, приведу власні бачення теоретичного обгрунтування визначення інституту виконання судових та інших рішень.

На думку авторів, процес судового захисту прав особи доцільно поділяти на три стадії:

1)правовий захист прав та інтересів особи у суді першої інстанції;

2)правовий захист прав та інтересів особи під час перегляду рішення;

3)правовий захист прав та інтересів особи під час виконання рішення.

Також пропонується стадію виконання рішення розмежувати на наступні підстадії:

- звернення судового рішення до виконання;

- початок процедури виконання рішення;

- добровільне виконання рішення;

- підготовка до примусового виконання рішення;

- власне примусове виконання рішення;

- контроль за належністю виконання рішення;

- завершення процедури виконання рішення.

Розглянувши теоретичні аспекти проблематики виконання рішень, автор дослідив сучасний стан виконавчого провадження та зосередив увагу на тому, що протягом 2016-2017 років відбулись суттеві законодавчі зміни щодо виконання судових рішень [3];[9]. Дані зміни відбулись без дос- 
татньої попередньої наукової дискусії, не було здійснено теоретичних обгрунтувань, тому практичні працівники сфери виконання рішень виконують свої повноваження, стикаючись із чисельними колізіями та прогалинами, які потребують негайного нормативного врегулювання.

Оновлення українського законодавства, яке врегульовує інститут виконання судових рішень та рішень інших органів (посадових осіб), обумовило появу нової правової категорії суб'єктів процесу - приватних виконавців [3]. Відсутність наукових досліджень правового статусу приватних виконавців та коректного тлумачення їх прав та обов'язків, актуалізує питання щодо аналізу їх правового положення в правовідносинах 3 примусового виконання рішень.

Не зважаючи на те, що в Україні вже функціонують приватні виконавці, наукова дискусія точиться щодо доцільності запровадження даного інституту, його підпорядкування та правової суті. Впровадження інституту приватних виконавців стало нововведенням в практиці примусового виконання рішень, яке, звісно, активно обговорюється в наукових колах. Здійснений аналіз правової літератури показав, що дискусія щодо цього питання синхронно відбувається в декількох напрямах. Перш за все, ряд науковців зосереджують увагу на питаннях переваг та недоліків інституту приватних виконавців протиставляючи його інституту державних виконавців. Інші колеги здійснюють аналіз природи та сутності категорії «приватний виконавець». Необхідно визнати, що в сучасних умовах становлення даного інсти- туту, усі наукові дослідження мають значення для обгрунтування подальшого розвитку виконавчого провадження в Україні.

Ряд вчених-правознавців вважають, що до переваг впровадження в Україні інституту приватних виконавців, слід віднести підвищення якості надання послуг із примусового виконання рішень, а також виведення інституту примусового виконання на якісно новий організаційно-правовий рівень, суттєве зниження бюджетних витрат на утримання виконавців, збільшення фінансових надходжень до державного бюджету, зниження корупційної складової у системі виконання [10].

Слушною, на погляд автора, є думка колег, які дійшли висновку, що впровадження інституту приватних виконавців - це суттєвий крок в системі реформування державного управління, оскільки він має характеризується значною кількістю переваг. Приватні виконавці законодавчо наділені широким колом повноважень, вони мають статус самозайнятих осіб, що виводить їх на статусний рівень адвоката чи нотаріуса. Законом також розмежовано компетенції приватних та державних виконавців, в залежності від категорії проваджень. Не зважаючи на значну чисельність процедурних прав, законодавець встановив механізм відповідальності за порушення та зловживання своїми правами для останніх [3]. На сьогодні, коли в Україні відбувся перехід до комбінованої системи забезпечення виконавчого провадження, слід зосередити увагу не стільки на питаннях підпорядкуванності, скільки на проблемах повноцінного вдоскона- 
ленні діяльності приватних виконавців, розширення їх повноважень.

Законом України «Про органи та осіб, які здійснюють примусове виконання судових рішень і рішень інших органів» визначено правовий статус приватних виконавців в Україні [3]. У Законі містяться норми, які закріплюють організаційні та юридичні вимоги до формування складу приватних виконавців. Наприклад, ст.18 Закону, що встановлює вимоги до особи приватного виконавця: наявність громадянства України, досягнення 25 років, наявність вищої юридичної освіти, володіння державною мовою тощо. Також ч.2 ст.18 цього Закону, визначає певні обмеження щодо осіб, які претендують на статус приватного виконавця: наявність судимості, визнання судом особи обмеженою у цивільній дієздатності або недієздатною тощо. Безперечно, такий перелік $\epsilon$ цілком обгрунтованим, оскільки примусове виконання рішень передбачає, що уповноважена особа має достатній високий рівень правосвідомості та наділена відповідними моральновольовими якостями. Саме у зв'язку 3 цим, у ч.3 ст.18 Закону встановлені обмеження до приватного виконавця, який під час здійснення своєї діяльності не може займатися іншою оплачуваною (крім викладацької, наукової i творчої діяльності, діяльності арбітражного керуючого (розпорядника майна, керуючого санацією, ліквідатора), інструкторської та суддівської практики із спорту та роботи в органах Асоціації приватних виконавців України) або підприємницькою діяльністю [3].
Проведене дослідження теоретичних та правових засад діяльності інституту приватних виконавців, дає змогу зробити висновок, що на сучасному етапі він $є$ комплексним правовим інститутом, що має особливий організаційний порядок формування, власну структурну надбудову у вигляді Асоціації приватних виконавців та кваліфікаційної комісії, а також адміністративно-територіальні межі здійснення діяльності на закріплених виконавчих округах. Зважаючи на незначний час діяльності приватних виконавців в Україні, необхідно визнати, що впровадження комбінованого механізму примусового виконання судових рішень та рішень інших органів (посадових осіб) є розумним та далекоглядним кроком, оскільки конкуретність на ринку послуг, беззаперечно призводить до підвищення їх якості. Законодавець, довіривши приватним виконавцям надважливу сферу адміністративно-процедурної діяльності, здійснив сміливий крок в напрямку підвищення соціально-правового статусу особи у здійсненні правовідносин. Для України це є нетиповим досвідом, оскільки за попередню історію держави не було прикладів примусового виконання рішень органів влади приватними особами, хоч і наділеними відповідними повноваженнями та статусністю.

Альтернативне функціонування приватного та державного інститутів примусового виконання може стати започаткуванням процесу звільнення від корупції даної сфери, оскільки суть діяльності приватного виконавця полягає в максимальному вирішенні інтересів стягувача. Це зумовлено 
двума факторами. По-перше, розмір грошової винагороди приватного виконавця напряму залежить від розміру стягненної з боржника суми. По-друге, збільшення кількості приватних виконавців в межах округу, зумовлює високу конкуренцію, що змушує виконавця систематично дбати про свою ділову репутацію і не допускати протиправних дій. Звичайно, держава повинна законодавчо та організаційно сприяти розвитку інституту приватних виконавців, який має повністю або ж значною мірою замінити систему примусового державного виконання.

\section{Список використаної літератури}

1. Курс цивільного процесу: підручник / В.В. Комаров, В.А. Бігун, В.В. Баранкова та ін.; за ред. В.В. Комарова. Харків: Право, 2011. 1352 с.

2. Балюк І.А. Господарське процесуальне право: навч. посібник. Київ: КНЕУ, 2008. 224 c.

3. Про органи та осіб, які здійснюють примусове виконання судових рішень $\mathrm{i}$ рішень інших органів : Закон України від 02.06.2016 року № 1403-VIII. URL: http://zakon3.rada.gov.ua/laws/show/1403-19.

4. Васильєв С. В. Господарський процес України: підручник. Харків: Еспада, 2010. 288 с.

5. Цивільний процес України: академічний курс: підручник для студ. юрид. спец. вищ. навч. закл. / за ред. С.Я. Фурси. Київ: Видавець Фурса С.Я.: КНТ, 2009. $848 \mathrm{c}$.

6. Цивільне процесуальне право: підручник / І. С. Ярошенко, I. О. Ізарова, О. М. Єфімов та ін.; за заг. ред. І. С. Ярошенко. К.: КНЕУ, 2014. 519 с.

7. Цивільний процес: пібручник / за заг. ред. Р.М. Мінченко, І.В. Андронов та ін. - 2-е вид., переробл. і доповн. Київ: Інститут законодавства Верховної Ради , 2016. $756 \mathrm{c}$.

8. Навроцька Ю.В., Верба-Сидор О.Б., Воробель У.Б. Цивільне процесуальне право України: навч. посіб. (у схемах і таблицях) / за заг. ред. Ю.В. Навроцької. Львів: ЛДУВС, 2013. 388 с.

9. Про виконавче провадження: Закон України від 02.06.2016 року № 1404VIII// URL: http://zakon2.rada.gov.ua/laws/show/1404-19.

10. Сайко Л.Ю., Ляшенко В.В. Правові аспекти запровадження інституту приватних виконавців в Україні. Молодий вчений. 2015. № 5(3). С.75-78.

11. Солонар А.В., Васильєва В.В. До питання запровадження інституту приватних виконавців в Україні. Юридичний науковий електронний журнал. 2016. №1. C. 65-68. 